\title{
De invloed van een beslissingsondersteunend hulpmiddel en ervaring op de beoordeling van AO/IC- beschrijvingen
}

Citation for published version (APA):

Broecheler, V. K., \& Vaassen, E. H. J. (1996). De invloed van een beslissingsondersteunend hulpmiddel en ervaring op de beoordeling van AO/IC-beschrijvingen. METEOR, Maastricht University School of Business and Economics. METEOR Research Memorandum No. 026 https://doi.org/10.26481/umamet.1996026

Document status and date:

Published: 01/01/1996

DOI:

10.26481/umamet.1996026

Document Version:

Publisher's PDF, also known as Version of record

Please check the document version of this publication:

- A submitted manuscript is the version of the article upon submission and before peer-review. There can be important differences between the submitted version and the official published version of record.

People interested in the research are advised to contact the author for the final version of the publication, or visit the DOI to the publisher's website.

- The final author version and the galley proof are versions of the publication after peer review.

- The final published version features the final layout of the paper including the volume, issue and page numbers.

Link to publication

\footnotetext{
General rights rights.

- You may freely distribute the URL identifying the publication in the public portal. please follow below link for the End User Agreement:

www.umlib.nl/taverne-license

Take down policy

If you believe that this document breaches copyright please contact us at:

repository@maastrichtuniversity.nl

providing details and we will investigate your claim.
}

Copyright and moral rights for the publications made accessible in the public portal are retained by the authors and/or other copyright owners and it is a condition of accessing publications that users recognise and abide by the legal requirements associated with these

- Users may download and print one copy of any publication from the public portal for the purpose of private study or research.

- You may not further distribute the material or use it for any profit-making activity or commercial gain

If the publication is distributed under the terms of Article $25 \mathrm{fa}$ of the Dutch Copyright Act, indicated by the "Taverne" license above, 


\section{De invloed van een beslissingsondersteunend hulpmiddel en ervaring op de beoordeling van AO/IC-beschrijvingen}

\section{Samenvatting}

Bij het afnemen van examens Administratieve Organisatie wordt er van uitgegaan dat het oordeel van de beoordelaar, al dan niet in samenspraak met een tweede beoordelaar, een juiste indicator is van de kwaliteit van een uitwerking. Consensus tussen beoordelaren wordt in het algemeen beschouwd als een goede maatstaf voor beslissingskwaliteit. Dit artikel onderzoekt in hoeverre onderwijs- en examenervaring enerzijds en het gebruik van een checklist anderzijds kunnen bijdragen aan het bereiken van meer consensus onder beoordelaren.

\section{Inleiding}

Controlerend accountants baseren zich bij de samenstelling van hun controleprogramma op een - al dan niet - geformaliseerde risico-analyse. In een dergelijke risico-analyse wordt - voorafgaand aan de controle - een inschatting gemaakt van de risico's waaraan de te controleren onderneming is blootgesteld, de risico's dat het systeem van administratieve organisatie en interne controle (AO/IC) bepaalde risico's onvoldoende opvangt, en de risico's dat de accountant de risico's die niet door het systeem van AO/IC zijn opgevangen niet signaleert. Op basis van een dergelijke risico-analyse maakt de accountant een onderscheid in systeemgerichte controlemaatregelen en gegevensgerichte controlemaatregelen. Globaal kan worden gesteld dat hoe beter de kwaliteit van de AO/IC, hoe meer de accountant bij zijn controle zal steunen op die AO/IC en hoe meer systeemgerichte controles hij zal uitvoeren. Bij de planning van de systeemgerichte controlemaatregelen beoordeelt de accountant de opzet van het systeem van AO/IC. Informatie over de opzet van het systeem van AO/IC verkrijgt de accountant door interviews met bedrijfsfunctionarissen te houden, door systeembeschrijvingen te lezen, door systeemstroomschema's te analyseren en in het algemeen door alert te zijn op voor de AO/ICbeoordeling relevante zaken. Kortom, de accountant vergaart reeds in een vroeg stadium van de controle informatie over de kwaliteit van de AO/IC.

Algemeen wordt verondersteld dat een accountant door zijn deskundigheid in staat is een systeem van IC te beoordelen op zijn kwaliteit, met andere woorden: te toetsen aan een normatieve IC-beschrijving. Normatieve IC-beschrijvingen voor bepaalde typen ondernemingen staan veelal beschreven in AO/ICtekstboeken en in controlehandboeken van accountantskantoren. Echter, cliëntspecifieke normatieve IC-beschrijvingen moeten worden ontwikkeld door de accountant op basis van zijn kennis en kunde, dat wil zeggen zijn bestaande cognitieve structuren. Accountancy-studenten moeten dus vaardigheden ontwikkelen om cliëntspecifieke normatieve IC-beschrijvingen samen te stellen. Traditioneel worden accountancy-studenten getraind in het uitwerken van cases betreffende een groot aantal verschillende bedrijven. De tijdens deze trainingen gemaakte normatieve IC-beschrijvingen worden beoordeeld door accountants met onderwijservaring die in meer of mindere mate praktijkervaring hebben. Dus: de interne controle-kennis en -kunde van accountants wordt niet slechts toegepast in het evalueren van ICsystemen van cliënten, maar ook in het evalueren van IC-beschrijvingen zoals samengesteld door studenten in het kader van trainingsprogramma's en examens.

Cognitieve structuren van accountants - bestaande uit productiesystemen, categorieën en schemata ${ }^{1}$ ontwikkelen zich naarmate de accountant die structuren aanspreekt (Waller \& Felix, 1984), wat in eerste instantie betekent dat accountants die ervaring hebben in het beoordelen van IC-beschrijvingen beschikken over uitgebreidere productiesystemen. Tussen de ontwikkeling van productiesystemen enerzijds en de ontwikkeling van schemata en categorieën anderzijds bestaat echter een zekere interactie. Bijvoorbeeld: bij het vervullen van een controle-opdracht zal de accountant zijn kennis omtrent getrouw beeld, materialiteit en controlemiddelen aanwenden om te komen tot een verklaring. De desbetreffende kennis wordt gerepresenteerd middels schemata. Tijdens de uitvoering van een specifieke controle-opdracht doet de accountant ervaring op met dat ene type cliënt. Daarbij ontwikkelt de accountant kennis inzake onder andere getrouw beeld, materialiteit en controlemiddelen bij dat specifieke type cliënt. Deze kennis slaat hij op in een productiesyteem. Naarmate de accountant meer controles uitvoert en daarbij dus ervaring opdoet met meer verschillende typen cliënten, leert de

1 Productiesystemen zijn hierarchieën van conditie-actie paren. Categorieën zijn cognitieve structuren die kennis primair organiseren op basis van gelijksoortigheid. Schemata zijn cognitieve structuren die kennis primair organiseren op basis van tijdruimtelijke relaties tussen kenniselementen. Zoals blijkt uit de omschrijvingen van categorieën en schemata is het onderscheid niet altijd ondubbelzinnig aan te geven. Dit is voor sommige auteurs aanleiding om slechts de term 'schemata' naast de term 'productiesystemen' te hanteren. 
accountant te discrimineren tussen de conditie-actie paren die gelden voor verschillende typen cliënten. De desbetreffende kennis wordt gerepresenteerd middels categorieën. Ervaring leidt dus niet slechts tot uitgebreidere productiesystemen, maar tevens tot uitgebreidere schemata (meer interrelaties tussen kenniselementen) en categorieën (meer discriminerend vermogen tussen verschillende typen cliënten). Het voorgaande betekent dat accountants die meer ervaring hebben op het gebied van IC-beoordeling waarschijnlijk over een grotere deskundigheid op het gebied van AO/IC-beoordelingen beschikken dan minder ervaren accountants. Voor de opleiding van accountants betekent dit dat accountants die meer ervaring hebben in het toekennen van cijfers aan IC-beschrijvingen zoals samengesteld door accountancy-studenten waarschijnlijk over meer deskundigheid inzake het beoordelen van ICbeschrijvingen beschikken.

Een grotere deskundigheid leidt in het algemeen tot snellere en betere beslissingen. In de praktijk van de accountantscontrole zal dit blijken uit het feit dat accountants beter in staat zijn te beoordelen of een IC-systeem - zoals aangetroffen bij een cliënt - in overeenstemming is met een normatief IC-systeem. In de opleiding tot accountant zal superieur beslissingsgedrag blijken uit het feit dat docenten beter in staat zijn de goede van de slechte IC-beschrijvingen zoals samengesteld door accountancy-studenten te onderscheiden en op basis daarvan betere feedback naar deze studenten te verzorgen. De accountantsopleiding moet een gezonde basis vormen voor accountancy-studenten om goede beoefenaren van het accountantsvak te worden. Als accountantskantoren de concurrentie in de markt voor zakelijke dienstverlening het hoofd willen blijven bieden, moeten ze er voor zorgen dat ze mensen aannemen die beschikken over die gezonde basis. Omdat personeel dat cursussen volgt niet productief is, hebben accountantskantoren er belang bij dat hun mensen de desbetreffende cursussen zo snel mogelijk afronden en het accountantsexamen behalen. Dit betekent dat accountantsopleidingen voortdurend moeten uitkijken naar manieren om het onderwijsleerproces te verbeteren in termen van efficiency en effectiviteit.

Beslissingsondersteunende hulpmiddelen kunnen bijdragen aan een grotere efficiency en effectiviteit van de accountantsopleiding omdat docenten, bij gebruikmaking van die hulpmiddelen, wellicht beter onderscheid kunnen maken tussen goede en slechte IC-beschrijvingen zoals samengesteld door studenten en derhalve betere feedback kunnen geven naar die studenten. Dit betekent dat de ontwikkeling van beslissingsondersteunende hulpmiddelen indirect leidt tot een superieure deskundigheidsontwikkeling onder accountancy-studenten. Verder kan de ontwikkeling van beslissingsondersteunende hulpmiddelen ertoe bijdragen dat de deskundigheid van enkelen, op grote schaal ingezet kan worden waardoor ook door minder ervaren en dientengevolge minder deskundige docenten snellere en betere beslissingen genomen kunnen worden dan mogelijk zou zijn zonder gebruikmaking van de desbetreffende beslissingsondersteunende hulpmiddelen.

Bij de term beslissingsondersteunende hulpmiddelen hoeft niet meteen gedacht te worden aan geavanceerde computers met dito programmatuur (expert-systemen dan wel beslissingsondersteunende systemen voor what/if-analyses zoals decision support systems, DSS). Ook checklists ten behoeve van de beoordeling van bepaalde fenomenen, algoritmen om bepaalde berekeningen te structureren en controlerichtlijnen zijn te beschouwen als beslissingsondersteunende hulpmiddelen. De ontwikkeling van een checklist, bestaande uit elementen die de kwaliteit van een IC-systeem zouden verbeteren, als een model van de expertise van ervaren docenten zou kunnen bijdragen aan de efficiency en effectiviteit van het vak $A O$ in de accountantsopleidingen. Aldus zou een betere deskundigheidsontwikkeling onder accountancy-studenten het resultaat kunnen zijn.

In dit artikel wordt onderzocht of de kwaliteit van beoordelingen van normatieve IC-beschrijvingen verbeterd kan worden als docenten met een verschillend aantal jaren beoordelingservaring bij het toekennen van cijfers gebruik maken van een checklist. Het resterende gedeelte van dit artikel bestaat uit de volgende onderdelen. In $\$ 2$ wordt een overzicht gegeven van bestaande literatuur op het gebied van consensus tussen accountants, beslissingsondersteunende hulpmiddelen en beslissingskwaliteit in de accountantscontrole. In $\S 3$ worden de onderzoeksvragen en de gehanteerde onderzoeksmethode besproken. In $\S 4$ worden de resultaten van het onderzoek gepresenteerd. In $\S 5$ tenslotte, worden conclusies getrokken naar aanleiding van het onderzoek en worden de onvermijdelijke beperkingen van de gehanteerde onderzoeksopzet gepresenteerd. 


\section{Achtergrondliteratuur}

De laatste decennia is er veel onderzoek gedaan op het gebied van consensus onder accountants. Uit een onderzoek van Ashton (1974) bleek dat accountants consistent waren in het maken van interne controle-beoordelingen. Joyce (1976) vergeleek controleprogramma's tussen verschillende accountantskantoren en binnen accountantskantoren. Het bleek dat binnen kantoren meer consensus bestond dan tussen kantoren. Moriarity \& Barron $(1976,1979)$ onderzochten de mate van consensus inzake materialiteit en materialiteitsbeïnvloedende factoren. Het bleek dat er nauwelijks sprake was van consensus. De resultaten uit diverse vervolgonderzoeken waren niet eenduidig. Mock \& Turner (1981), Gaumitz et al. (1982) en Tabor (1983) vonden in hun onderzoek dat accountants over het algemeen een hoge mate van consensus vertoonden. Echter Ashton \& Kramer (1980) en Ashton \& Brown (1980) vonden juist een lage mate van consensus onder accountants. Uit een onderzoek van Ashton (1985) waarin als eerste een vergelijking tussen consensusmaatstaven en beslissingskwaliteit gemaakt werd bleek dat er een positieve relatie was tussen consensus en beslissingskwaliteit. Bedard (1991) vond dat er onder ervaren accountants meer consensus bestond indien de AO/IC van hoge kwaliteit was en minder indien de AO/IC van lage kwaliteit was.

Brown (1962) ontwikkelde een interne controle-vragenlijst en kende aan elk element uit die vragenlijst wegingsfactoren toe ter bepaling van een effectiviteitsindex van de $\mathrm{AO} / \mathrm{IC}$. Hij stelde dat hoe hoger deze effectiviteitsindex voor een bepaalde cliënt, hoe meer bij de accountantscontrole gesteund kon worden op de AO/IC. Naar aanleiding van dit onderzoek kunnen twee belangrijke opmerkingen worden gemaakt: ten eerste, het was één van de eerste onderzoeken waarbij het subjectieve proces van vakkundige oordeelsvorming door de controlerend accountant object van studie was, en ten tweede, er lag geen empirisch materiaal aan ten grondslag waardoor de toegekende wegingsfactoren tamelijk arbitrair waren. Uit verder onderzoek op het gebied van beslissingsondersteunende hulpmiddelen en beslissingskwaliteit bleek: (1) dat betere beslissingen werden genomen bij gebruik van een beslissingsondersteunend hulpmiddel in de vorm van een simulatieprogramma gekoppeld aan een systeem voor what/if-analyses (Weber, 1978), (2) dat een uitbreiding van richtlijnen inzake steekproefbepaling slechts een marginaal neerwaarts effect had op de steekproefomvang (Mock \& Turner, 1981), (3) dat consensus afnam naarmate meer gebruik werd gemaakt van een beslissingsondersteunend hulpmiddel in de vorm van een algoritme (Kachelmeier \& Messier, 1990), en (4) dat leereffecten bij gebruik van een beslissingsondersteunend hulpmiddel in de vorm van een expert-systeem kleiner waren dan zonder gebruik van een beslissingsondersteunend hulpmiddel (Murphy, 1990).

Het gebruik van een beslissingsondersteunend hulpmiddel, gericht op het verbeteren van de kwaliteit van beslissingen, kan worden bestudeerd vanuit de optiek van helderheid van doeleinden. Als er géén strakke richtlijnen voor prestatie-beoordeling zijn, dan is het mogelijk dat beoordelaren op inadequate wijze discrimineren tussen goede en slechte prestaties (Milkovich \& Newman, 1993, pp. 297-299; Ilgen et al., 1993). Een beslissingsondersteunend hulpmiddel zal, middels strakkere prestatiebeoordelingsmaatstaven, een grotere helderheid van doeleinden creëren. Enkele onderzoeksresultaten op dit terrein zijn: (1) specifieke standaarden simplificeren het vergelijken van werkelijke met verwachte prestaties (Tversky, 1977), (2) specifieke standaarden verbeteren de kwaliteit van de feedback (Luckett \& Eggleton, 1991), en (3) specifieke standaarden maken het voor de beoordelaar mogelijk een onderscheid te maken tussen acceptabele en onacceptabele resultaten, en dragen zo bij aan een nauwkeurigere prestatiebeoordeling (Huber, 1989, p. 545). Samenvattend kan worden gesteld: doordat een beslissingsondersteunend hulpmiddel kan bijdragen tot meer helderheid van doelen, kan het gebruik van zo'n hulpmiddel leiden tot grotere beoordelingsnauwkeurigheid.

Libby en Luft (1993) presenteren een model voor het leren door ervaring waarbij talent en ervaring als verklarende factoren voor kennis en beslissingsgedrag worden gehanteerd. Bonner \& Lewis (1990) stellen dat superieure besluitvorming, dus beslissingsgedrag van experts, bepaald wordt door opleiding, relevante werkervaring en talent.

\section{Onderzoeksmethode}


Op basis van voorgaand onderzoek kan een model worden ontwikkeld waarin de effecten van beslissingsondersteunende hulpmiddelen en ervaring op beslissingskwaliteit zijn gerepresenteerd. Omdat het gebruik van beslissingsondersteunende hulpmiddelen (Huber, 1989) en ervaring (Bonner \& Lewis, 1990) tot superieur beslissingsgedrag leidt, is de verwachting dat onervaren beslissers hun besluitvorming kunnen verbeteren door toepassing van een beslissingsondersteunend hulpmiddel. Verder is de verwachting dat consensus zal toenemen als de beslissingskwaliteit toeneemt (Ashton, 1985). Het model dat getest wordt is weergegeven in figuur 1.

\section{Onderzoeksvragen}

Er zijn twee dichotome variabelen die, geïsoleerd of in combinatie, de mate van consensus en de hoogte van de toegekende cijfers kunnen verklaren: de behandeling (wel/geen checklist) en beoordelingservaring (ja/nee). Om de relatie tussen behandeling, ervaring en consensus vast te stellen, worden de volgende onderzoeksvragen gesteld:

\section{Vraag 1:}

Leidt toepassing van een checklist $\mathrm{AO} / \mathrm{IC}$ tot meer consensus onder beoordelaren?

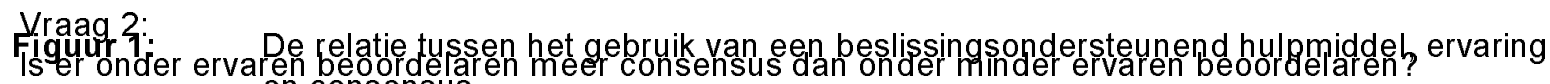
en consensus.

Vraag 3:

Zijn er interactie-effecten van ervaring en gebruikmaking van een checklist op de mate van consensus?

OMeslissings feellen of er neveneffecten optreden op de hoogte van de toegekende cijfers, worden de voldersteunn fund

Vraag 4:

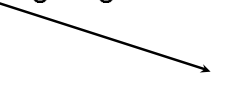

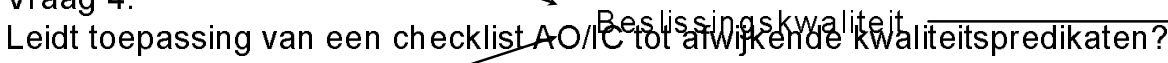

Consensus

Vraaq 5:

Geven ervarên beoordelaren andere kwaliteitspredikaten dan minder ervaren beoordelaren?

Vraag 6:

Zijn er interactie-effecten van ervaring en gebruikmaking van een checklist op de hoogte van de kwaliteitspredikaten?

Taak

Er werd een experiment opgezet waarbij aan subjecten werd gevraagd de uitwerkingen van twee studenten van een AO-case te beoordelen op een schaal van 1 tot 10 . Er werden twee groepen subjecten onderscheiden:

- $\quad$ groep 0; alle uitwerkingen dienden beoordeeld te worden aan de hand van een normatieve oplossing in de vorm van een traditioneel schema van uitwerking;

groep 1; alle uitwerkingen dienden beoordeeld te worden aan de hand van een normatieve oplossing in de vorm van een traditioneel schema van uitwerking aangevuld met een checklist bestaande uit 97 elementen verdeeld over 9 categorieën.

In de checklist moest per uitwerking aangegeven worden of elk element op correcte wijze was verwerkt $(\operatorname{code}=1)$ dan wel afwezig of incorrect was verwerkt $(\operatorname{code}=0)$.

\section{Subjecten}

De onderzoekspopulatie bestond uit 53 Registeraccountants en 22 post-doctorale accountancystudenten. De Registeraccountants hadden een gemiddelde beoordelingservaring van 12,82 jaren. Verder waren ze allen verbonden aan het NIVRA danwel aan één van de postdoctorale opleidingen tot Registeraccountant of Registercontroller in Nederland. De studenten hadden geen beoordelingservaring maar hadden wel het landelijk schriftelijk AO-examen behaald.

Case

De case die gebruikt werd was een examencase van het NIVRA zoals die in het voorjaar van 1987 aan 
examenkandidaten werd aangeboden. Het betrof een productie-onderneming in de fijnmechanische industrie. Het bijbehorende schema van uitwerking was samengesteld door de redactiecommissie die ook de case-beschrijving had gemaakt. Gezien de zwaarwegende belangen, de deskundigheid van de redactiecommissieleden en het feit dat er in de normeringsvergadering na afloop van het examen consensus over de inhoud werd bereikt, zijn er géén redenen om aan te nemen dat het aldus samengestelde schema van uitwerking ernstige tekortkomingen vertoont. Aangezien er géén checklist bij het schema van uitwerking was bijgevoegd, diende deze door de onderzoekers ontwikkeld te worden. Om ervoor zorg te dragen dat de samen te stellen checklist en het schema van uitwerking volledig onderling vergelijkbaar waren, diende er een één op één relatie te bestaan tussen de checklist en het schema van uitwerking, wat er op neerkwam dat in de checklist slechts die elementen mochten worden opgenomen die ook in het schema van uitwerking waren opgenomen en dat alle elementen uit het schema van uitwerking in de checklist werden opgenomen. Om te waarborgen dat de ontwikkeling van die checklist zo objectief mogelijk zou plaatsvinden, werd de volgende procedure gevolgd:

1. Er werden twee onafhankelijke samenstellers en een onafhankelijke derde geselecteerd die voldeden aan de criteria:

- geslaagd voor het landelijk schriftelijk en mondeling examen administratieve organisatie;

- $\quad$ minimaal twee jaren ervaring in het corrigeren van AO-uitwerkingen.

2. leder van de samenstellers stelde onafhankelijk een concept-checklist samen.

3. De elementen uit de concept-checklisten werden door de onafhankelijke derde gematched eventueel na aanpassing van de bewoordingen - en van een eenduidige nummering voorzien.

4. Alle elementen die voorkwamen in één van beide checklisten werden door de onafhankelijke derde geclassificeerd in drie categorieën"

- $\quad$ niet aanwezig in de concept-checklist van samensteller $A$, wèl aanwezig in de conceptchecklist van samensteller $B(\mathrm{NJ})$;

wèl aanwezig in de concept-checklist van samensteller A, niet aanwezig in de conceptchecklist van samensteller $B(\mathrm{JN})$;

zowel aanwezig in de concept-checklist van samensteller $A$ als in de concept-checklist van samensteller $B(J J)$.

5. Op basis van de classificatie in de categorieën van de elementen uit de checklist waarover géén overeenstemming bestond $(\mathrm{NJ}$ of $\mathrm{JN})$ vond afstemming plaats tussen beide samenstellers in aanwezigheid van de onafhankelijke derde.

In bijlage 1 zijn de case, het schema van uitwerking alsmede de definitieve afgestemde checklist integraal weergegeven. In bijlage 2 zijn de instructies ten behoeve van de onafhankelijke derde inzake de matching van de checklists opgenomen.

\section{Resultaten}

Toegekende kwaliteitspredikaten

De aan de twee uitwerkingen toegekende kwaliteitspredikaten zijn weergegeven in tabel 1 . Het blijkt dat er zowel onder ervaren als onder minder ervaren beoordelaren grote verschillen in kwaliteitsperceptie bestaan. Voor de normatieve AO/IC-beschrijving van student 1 (NICB 1) was het laagste cijfer 4,00 en het hoogste 7,60 (variatiebreedte: 3,60 ). Als een differentiatie naar ervaringscategorie werd gemaakt bleek de variatiebreedte voor de ervaren groep 3,60 te zijn en voor de minder ervaren groep 3,00. Voor de normatieve AO/IC-beschrijving van student 2 (NICB 2) was het laagste cijfer 3,00 en het hoogste 8,00 (variatiebreedte 5,00 ). Als een differentiatie naar ervaringscategorie werd gemaakt bleek de variatiebreedte voor de ervaren groep 3,70 te zijn en voor de minder ervaren groep 5,00.

Tabel 1: Frequentie van de toegekende cijfers, gedifferentieerd naar ervaringscategorie, in cijferklassen gerubriceerd.

2 Door deze werkwijze was het mogelijk de mate van overeenstemming tussen beide samenstellers vast te stellen. Als maatstaf werd het percentage overeenstemming gebruikt, dus: JJ/(JJ+JN+N.J). Het bleek dat over $(90 /(90+2+7)=91 \%$ van de elementen overeenstemming bestond 


\begin{tabular}{|c|c|c|c|c|c|c|}
\hline \multirow[t]{2}{*}{ Cijferklassen } & \multicolumn{2}{|c|}{ Beoordelingservaring } & \multirow[t]{2}{*}{ Totaal } & \multicolumn{2}{|c|}{ Beoordelingservaring } & \multirow[t]{2}{*}{ Totaal } \\
\hline & Nee & $\mathrm{Ja}$ & & $\mathrm{Nee}$ & $\mathrm{Ja}$ & \\
\hline & $N / C B 1$ & & & $N I C B 2$ & & \\
\hline $3,00-<3,50$ & 0 & 0 & 0 & 1 & 3 & 4 \\
\hline $3,50-<4,00$ & 0 & 0 & 0 & 0 & 3 & 3 \\
\hline $4,00-<4,50$ & 0 & 7 & 7 & 3 & 9 & 12 \\
\hline $4,50-<5,00$ & 3 & 6 & 9 & 5 & 10 & 15 \\
\hline $5,00-<5,50$ & 5 & 10 & 15 & 2 & 17 & 19 \\
\hline $5,50-<6,00$ & 6 & 8 & 14 & 4 & 3 & 7 \\
\hline $6,00-<6,50$ & 2 & 11 & 13 & 3 & 6 & 9 \\
\hline $6,50-<7,00$ & 2 & 3 & 5 & 2 & 2 & 4 \\
\hline $7,00-<7,50$ & 2 & 5 & 7 & 1 & 0 & 1 \\
\hline $7,50-<8,00$ & 2 & 3 & 5 & 0 & 0 & 0 \\
\hline $8,00-<8,50$ & 0 & 0 & 0 & 1 & 0 & 1 \\
\hline Totaal & 22 & 53 & 75 & 22 & 53 & 75 \\
\hline
\end{tabular}

Onderzoeksvraag 1

Onderzoeksvraag 1 (leidt toepassing van een checklist AO/IC tot meer consensus onder beoordelaren?) werd onderzocht middels een F-toets op het verschil tussen de standaarddeviaties van de cijfers binnen de groep case-uitwerkingen waarbij géén checklist werd gebruikt en de standaarddeviaties van de cijfers binnen de groep case-uitwerkingen waarbij wèl de checklist werd gebruikt. De gedachte achter toepassing van een toets op de standaarddeviaties is dat indien de standaarddeviatie afneemt, consensus toeneemt en vice versa (Ashton, 1985). De hypothese bij deze onderzoeksvraag was dat toepassing van een checklist AO/IC leidt tot meer consensus onder beoordelaren. Het bleek dat de standaarddeviaties tussen de groep die níet en de groep die wél de checklist hadden gebruikt significant verschilden (bij $\alpha=0,10$ ) in de verwachte richting voor NICB 1 , maar niet significant verschilden voor NICB 2 .

\section{Onderzoeksvraag 2}

Onderzoeksvraag 2 (Is er onder ervaren beoordelaren meer consensus dan onder minder ervaren beoordelaren?) werd onderzocht middels een F-toets op het verschil tussen de standaarddeviaties van de ervaren en van de onervaren groep beoordelaren. De hypothese bij deze onderzoeksvraag was dat ervaren beoordelaren meer consensus zullen vertonen dan minder ervaren beoordelaren. Het bleek dat de standaarddeviaties van de ervaren en de onervaren groep niet significant verschilden (bij $\alpha=0,10$ ) voor NICB 1 , maar wel significant verschilden in de verwachte richting voor NICB 2 .

\section{Onderzoeksvraag 3}

Onderzoeksvraag 3 (Zijn er interactie-effecten van ervaring en gebruikmaking van een checklist op de mate van consensus?) werd ten eerste onderzocht middels een F-toets op het verschil tussen de standaarddeviaties voor de groep die wel en die niet gebruik maakte van de checklist voor zowel de ervaren als de onervaren beoordelaren. Ten tweede werd het onderzocht middels een F-toets op het verschil tussen de standaarddeviaties van de ervaren en de onervaren groep voor beide behandelingen (wel en geen gebruikmaking van de checklist). De hypothese bij deze onderzoeksvraag was dat er een interactie-effect is tussen ervaring en gebruikmaking van een checklist op de mate van consensus tussen de beoordelaren. Voor NICB 1 werd gevonden dat het niet-significante ervaringseffect ( $p$ waarde $=0,438$ ) ook niet significant was als naar behandeling werd gedifferentieerd: als géén checklist werd gebruikt dan was de p-waarde 0,602, als wél een checklist werd gebruikt dan was de p-waarde 
0,535 . Verder was het significante behandelingseffect ( $p$-waarde $=0,002$ ) ook significant als naar ervaringscategorie werd gedifferentieerd: de onervaren groep had een $p$-waarde van 0,094 , de ervaren groep had een $p$-waarde van 0,009 . Alhoewel beide verschillen significant zijn, is het effect van een checklist groter in de ervaren groep van beoordelaren. Voor NICB 2 werd gevonden dat het significante ervaringseffect ( $p$-waarde $=0,089$ ) niet significant was als naar behandeling werd gedifferentieerd: als géén checklist werd gebruikt dan was de $p$-waarde 0,591, als wél een checklist werd gebruikt dan was de $p$-waarde 0,937 . Verder was het niet significante behandelingseffect $(p$-waarde $=0,141)$ ook niet significant als naar ervaringscategorie werd gedifferentieerd: bij de onervaren groep was de $p$-waarde 0,571 , bij de ervaren groep was de p-waarde 0,878 . In tabel 2 zijn de resultaten betreffende onderzoeksvragen 1, 2 en 3 samengevat. 
Tabel 2: Resultaten van de toetsen op de standaarddeviaties per behandeling en per ervaringscategorie voor beide NICB-en.

\begin{tabular}{ccccccc}
\hline \hline \multirow{2}{*}{ NICB 1 } & & \multicolumn{4}{c}{ Checklist } \\
& & Totaal & Nee & Ja & p-waarde \\
\hline \multirow{2}{*}{ Beoordelingservaring } & Totaal & 0.965 & 1.165 & 0.773 & 0.002 \\
& Nee & 0.910 & 1.052 & 0.792 & 0.094 \\
& Ja & 0.989 & 1.215 & 0.778 & 0.009 \\
& p-waarde & 0.438 & 0.602 & 0.535 & n.v.t. \\
\hline \hline \multirow{2}{*}{ NICB 2 } & & & & \multicolumn{2}{c}{ Checklist } & \\
& & Totaal & Nee & Ja & p-waarde \\
\hline \multirow{2}{*}{ Beoordelingservaring } & Totaal & 0.977 & 0.936 & 0.761 & 0.141 \\
& Nee & 1.165 & 1.032 & 0.766 & 0.571 \\
& Ja & 0.865 & 0.786 & 0.770 & 0.878 \\
& p-waarde & 0.089 & 0.591 & 0.937 & n.v.t. \\
\hline \hline
\end{tabular}

\section{Onderzoeksvraag 4}

Onderzoeksvraag 4 (Leidt toepassing van een checklist AO/IC tot afwijkende kwaliteitspredikaten?) werd onderzocht middels een onafhankelijke t-toets op het verschil tussen de gemiddelden van de groep die wel en die niet gebruik maakte van de checklist. De hypothese bij deze onderzoeksvraag was dat toepassing van de checklist leidt tot afwijkende kwaliteitspredikaten. Het bleek dat de gemiddelde kwaliteitspredikaten van de groep mét en de groep zonder checklist niet significant verschilden (bij $\alpha=0,10$ ) voor NICB 1 , maar wél significant verschilden voor NICB 2: toepassing van de checklist leidde tot lagere kwaliteitspredikaten.

\section{Onderzoeksvraag 5}

Onderzoeksvraag 5 (Geven ervaren beoordelaren andere kwaliteitspredikaten dan minder ervaren beoordelaren?) werd onderzocht middels een onafhankelijke t-toets op het verschil tussen de gemiddelde cijfers van de ervaren en de onervaren groep beoordelaren. De hypothese bij deze onderzoeksvraag was dat ervaren beoordelaren een ander kwaliteitspredikaat geven dan minder ervaren beoordelaren. Het bleek dat de gemiddelde kwaliteitspredikaten gegeven door de ervaren en de onervaren groep niet significant verschilden (bij $\alpha=0,10$ ) voor beide NICB-en.

\section{Onderzoeksvraag 6}

Onderzoeksvraag 6 (Zijn er interactie-effecten van ervaring en gebruikmaking van een checklist op de hoogte van de kwaliteitspredikaten?) werd ten eerste onderzocht middels een onafhankelijke t-toets op het verschil tussen de gemiddelde cijfers gegeven door de groep met en zonder checklist voor beide ervaringscategoriën. Ten tweede werd deze vraag onderzocht middels een onafhankelijke t-toets op het verschil tussen de gemiddelde cijfers voor de ervaren en de onervaren groep voor beide behandelingen. De hypothese bij deze onderzoeksvraag was dat een combinatie van ervaring en de behandeling invloed heeft op de hoogte van de kwaliteitspredikaten. Voor NICB 1 bleek dat het nietsignificante ervaringseffect ( $p$-waarde $=0,410$ ) ook niet significant was als naar behandeling werd gedifferentieerd: als géén checklist werd gebruikt was de p-waarde 0,429 , als wél een checklist werd gebruikt was de $p$-waarde 0,773 . Verder was het niet-significante behandelingseffect ( $p$-waarde $=0,629$ ) ook niet significant als naar ervaringscategorie werd gedifferentieerd: bij de onervaren groep was de $p$ waarde 0,457 , bij de ervaren groep was de $p$-waarde 0,911 . Voor NICB 2 bleek dat het níet significante ervaringseffect ( $p$-waarde $=0,106$ ) wél significant was als géén checklist werd gebruikt ( $p$ waarde $=0,013$ ), en níet significant als wél een checklist werd gebruikt ( $p$-waarde $=0,637$ ). Verder was het significante behandelingseffect ( $p$-waarde $=0,000$ ) ook significant als naar ervaringscategorie werd 
gedifferentieerd ( $p$-waarde in beide gevallen=0,001). In tabel 3 zijn de resultaten betreffende onderzoeksvragen 4,5 en 6 samengevat.

Tabel 3: $\quad$ Resultaten van de toetsen op de gemiddelde kwaliteitspredikaten per behandeling en per ervaringscategorie voor beide NICB-en.

\begin{tabular}{|c|c|c|c|c|c|}
\hline \multirow[t]{2}{*}{ NICB 1} & & \multicolumn{4}{|c|}{ Checklist } \\
\hline & & Totaal & $\mathrm{Nee}$ & $\mathrm{Ja}$ & p-waarde \\
\hline & Totaal & 5.709 & 5.771 & 5.657 & 0.629 \\
\hline \multirow[t]{3}{*}{ Beoordelingservaring } & $\mathrm{Nee}$ & 5.852 & 6.020 & 5.713 & 0.457 \\
\hline & $\mathrm{Ja}$ & 5.649 & 5.667 & 5.635 & 0.911 \\
\hline & $\mathrm{p}$-waarde & 0.410 & 0.429 & 0.773 & n.v.t. \\
\hline \multirow[t]{2}{*}{ NICB 2} & & \multicolumn{4}{|c|}{ Checklist } \\
\hline & & Totaal & $\mathrm{Nee}$ & $\mathrm{Ja}$ & p-waarde \\
\hline \multirow{4}{*}{ Beoordelingservaring } & Totaal & 4.972 & 5.518 & 4.520 & 0.000 \\
\hline & $\mathrm{Nee}$ & 5.300 & 6.120 & 4.608 & 0.001 \\
\hline & $\mathrm{Ja}$ & 4.838 & 5.267 & 4.483 & 0.001 \\
\hline & p-waarde & 0.106 & 0.013 & 0.637 & n.v.t. \\
\hline
\end{tabular}

\section{Conclusie}

\section{Discussie}

De resultaten van deze studie verschaffen geen eenduidig bewijs omtrent de relatie tussen het gebruik van een beslissingsondersteunend hulpmiddel en ervaring aan de ene kant en consensus en de hoogte van het toegekende kwaliteitspredikaat aan de andere kant. De belangrijkste bevinding voor NICB 1 was dat consensus toenam als een checklist werd gebruikt. De belangrijkste bevindingen voor NICB 2 waren dat de door beoordelaren mét een checklist toegekende kwaliteitspredikaten lager waren dan die door beoordelaren zonder een checklist. Verder veroorzaakte ervaring alleen verschillen als géén gebruik werd gemaakt van de checklist: meer ervaring leidde tot lagere kwaliteitspredikaten voor NICB 2. Dit impliceert dat onervaren beoordelaren die wél een checklist gebruikten kwaliteitspredikaten toekenden die de kwaliteitspredikaten van de ervaren beoordelaren benaderden.

Gebaseerd op voorgaande bevindingen kan geconcludeerd worden dat er verschillen moeten zijn in de NICB-en, welke verschillen het gebrek aan eenduidig bewijs kunnen verklaren. Het meest in het oog springende verschil tussen de NICB-en is dat het gemiddelde toegekende kwaliteitspredikaat voor NICB 1: 5,709 is, terwijl dit voor NICB 2: 4,972 is. Het verschil tussen deze twee gemiddelden is significant bij $\alpha=0,10$ ( $p$-waarde $=0,000$ ). Omdat NICB 1 waarschijnlijk superieur is aan NICB 2, kunnen de onverwachte bevindingen wellicht verklaard worden op basis van dit verschil in kwaliteit tussen de NICB-en. De verklaring zou als volgt kunnen zijn. Van ervaren beoordelaren wordt verwacht dat zij een beoordelingsgedrag ten toon spreiden waarbij een groot verschil wordt gemaakt tussen superieure NICB-en en inferieure NICB-en. Dit, omdat zij de procedurele en de declaratieve kennis bezitten die het voor hen mogelijk maakt meer vertrouwen te hebben in hun beoordelingen. Verder wordt verwacht dat onder ervaren beoordelaren consensus bestaat over de kwaliteit van de NICB-en, omdat hun beslissingen de (onbekende) juiste beslissingen benaderen. Het verschil tussen het laagste toegekende kwaliteitspredikaat en het hoogste toegekende kwaliteitspredikaat voor dezelfde NICB door ervaren beoordelaren is dus klein. Daarentegen is het verschil tussen het hoogste toegekende kwaliteitspredikaat en het laagste toegekende kwaliteitspredikaat aan verschillende NICB-en juist groot, ervan uitgaande dat er werkelijk een verschil is in de kwaliteit van de NICB-en. Van onervaren 
beoordelaren wordt juist verwacht dat zij een klein onderscheid maken tussen superieure en inferieure NICB-en. Dit omdat zij waarschijnlijk niet de procedurele en declaratieve kennis bezitten die nodig is om vertrouwen te hebben in hun eigen beslissingen. Meer specifiek kan worden gezegd dat onervaren beoordelaren kwaliteitspredikaten zullen toekennen die dicht liggen bij de omslag van adequate naar niet adequate beschrijvingen. Deze kritieke grens ligt normaliter bij het cijfer 5,5. Dus, tussen onervaren beoordelaren is het verschil tussen het hoogste toegekende kwaliteitspredikaat en het laagste toegekende kwaliteitspredikaat aan verschillende NICB-en klein, zelfs als er een groot verschil in kwaliteit is tussen de NICB-en.

Concluderend kan worden gesteld dat de ervaren en de onervaren beoordelaren verschillen op twee manieren: ten eerste kan de variabiliteit binnen de groep ervaren beoordelaren groter zijn voor verschillende NICB-en, afhankelijk van een werkelijk verschil in kwaliteit, dan de variabiliteit van de onervaren beoordelaren door een besluitvormings-vertrouwen effect. Ten tweede kan de variabiliteit van de ervaren beoordelaren voor dezelfde NICB kleiner zijn dan de variabiliteit van de onervaren beoordelaren door een expertise effect. In figuur 2 zijn deze relaties grafisch weergegeven.

In het bovenste gedeelte van figuur 2 is de relatie tussen de mate van consensus en de kwaliteit van de NICB weergegeven. Onervaren beoordelaren zullen een lage mate van consensus hebben als de NICB of van een lage of van een hoge kwaliteit is (expertise effect). Verder zullen zij een hoge mate van consensus hebben bij een NICB van gemiddelde kwaliteit (besluitvormings-vertrouwen effect).

Figuur 2: $\quad$ De veronderstelde relatie tussen kwaliteit van de NICB, consensus, gemiddelde cijfer en het gebruik van een beslissingsondersteunend hulpmiddel $(\mathrm{BOH})$.

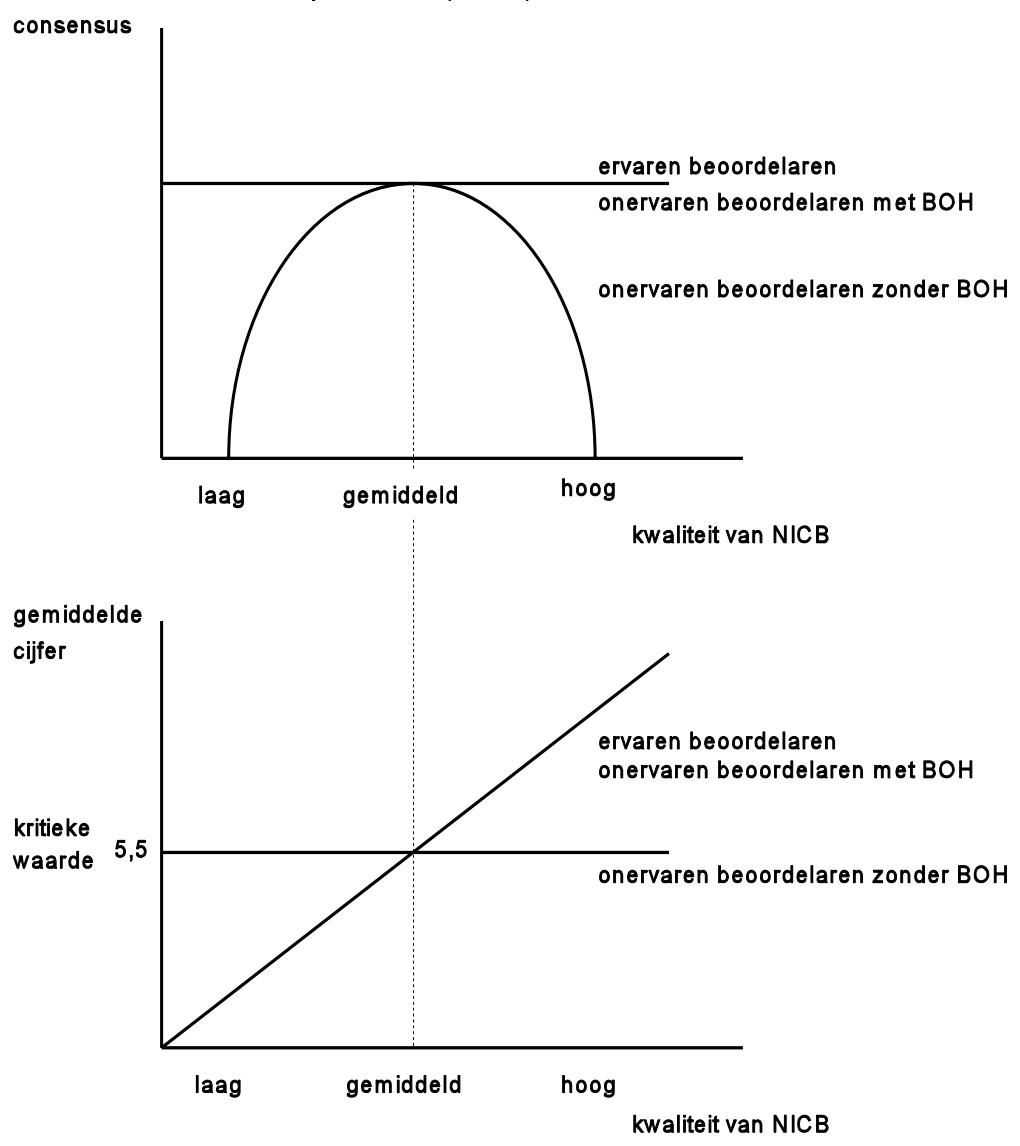

Ervaren beoordelaren zullen een hoge mate van consensus bezitten ongeacht de kwaliteit van de NICB (expertise effect). Echter, als onervaren beoordelaren een beslissingsondersteunend hulpmiddel 
gebruiken, dan zullen zij, evenals de ervaren beoordelaren, een hoge mate van consensus gaan vertonen ongeacht de de kwaliteit van de NICB.

In het onderste gedeelte van figuur 2 is de relatie tussen het gemiddelde cijfer en de kwaliteit van de NICB weergegeven. Onervaren beoordelaren zullen cijfers toekennen die neigen naar de kritieke waarde 5,5. Dit onafhankelijk van de werkelijke kwaliteit van de NICB, door het besluitvormingsvertrouwen effect. Ervaren beoordelaren zullen cijfers toekennen die in verhouding staan tot de werkelijke kwaliteit van de NICB. Dit door het expertise effect. Echter, als onervaren beoordelaren een beslissingsondersteunend hulpmiddel gebruiken, dan zullen zij cijfers toekennen die de cijfers van de ervaren beoordelaren benaderen. Bij het verklaren van het effect van ervaring op de hoogte van het toekennen van cijfers moet er dus een onderscheid gemaakt worden tussen beoordelaren die wel en die geen beslissingsondersteunend hulpmiddel gebruiken.

\section{Beperkingen en suggesties voor verder onderzoek}

De hierboven opgestelde redenering als verklaring van de resultaten lijkt aannemelijk. Echter, op basis van het tot nu toe verzamelde empirisch materiaal is het niet mogelijk om deze redenering te toetsen. Dit omdat in het onderzoek niet is gecontroleerd voor kwaliteit van de NICB-en. Een suggestie voor vervolgonderzoek is dan ook het opzetten van een experiment waarin zowel het gebruik van een beslissingsondersteunend hulpmiddel, ervaring als de kwaliteit van de NICB-en systematisch wordt gevarieerd. Uitgaande van de gehypothetiseerde kwadratische relatie tussen consensus en de kwaliteit van de NICB voor onervaren beoordelaren, moet de kwaliteit van de NICB gedifferentieerd worden in ten minste drie niveaus: laag, gemiddeld en hoog. Een alternatieve benadering voor de verificatie van de voorgestelde theorie van consensus en beoordelingsnauwkeurigheid is het uitvoeren van een metaanalyse op basis van empirische resultaten in het onderzoeksveld. Verder is de steekproefomvang in deze studie alleen adequaat als individuele effecten worden bekeken. Als interactie effecten worden bekeken wordt de steekproefomvang namelijk al snel te klein. Omdat in deze studie ook naar interactie-effecten is gekeken, is het beter de studie uit te breiden naar een grotere steekproefomvang.

\section{Implicaties voor theorie en praktijk}

Deze studie draagt bij aan audit judgment theorie in die zin dat ze een beter inzicht verschaft in het concept van ervaring en het gebruik van een beslissingsondersteunend hulpmiddel in relatie tot consensus en besluitvormingsnauwkeurigheid. Verder verschaft deze studie een prikkel voor het starten van een onderzoekprogramma gericht op het verifiëren van de voorgestelde theorie van consensus en besluitvormingsnauwkeurigheid. De bijdrage aan de audit praktijk is van een indirecte aard omdat de ontwikkeling van beslissingsondersteunende hulpmiddelen ten behoeve van onderwijsleerprocessen leidt tot een verhoogde effectiviteit (betere feedback aan studenten) en efficiency (meer gestandaardiseerde beoordelingen) binnen de opleiding tot accountant. 


\section{Bijlage 1}

\section{Case 'Fijnmechanische industrie'}

Een onderneming uit de fijnmechanische industrie houdt zich bezig met de productie en verkoop van een groot aantal soorten draad en toevoerdraden ten behoeve van de elektrotechnische industrie. De productie geschiedt op voorraad.

In de onderneming zijn 200 personen werkzaam.

Onder de directie ressorteren onder meer de volgende afdelingen:

- productie.

Onder het hoofd van de productie-afdeling ressorteren:

. bedrijfsbureau;

. afdeling draadtrekkerij;

. afdeling toevoerdraden;

- magazijn;

- inkoop;

- verkoop;

- administratie;

- automatisering.

Door de onderneming worden geproduceerd:

- Draad.

In de afdeling draadtrekkerij wordt zowel draad van één metaalsoort (koper of nikkel) geproduceerd als draad van een legering. Geproduceerd draad wordt gebruikt ten behoeve van de vervaardiging van toevoerdraden danwel verkocht aan derden.

- Toevoerdraden.

In de afdeling toevoerdraden wordt draad geknipt in staafjes van 5 tot 10 centimeter, waarna staafjes van verschillende draadsoorten worden aaneengelast. Toevoerdraden worden gebruikt door lampenproducenten ten behoeve van de productie van gloeilampen.

Inkoop van kostbare metalen die voor de productie worden gebruikt, vindt plaats bij metaalfabrieken in binnen- en buitenland. De inkoopprijzen fluctueren als gevolg van de marktomstandigheden. Bij de productie van draad en toevoerdraden ontstaat vrij kostbaar metaalafval.

Verkoop van draad en toevoerdraden vindt plaats per lengte-eenheid aan de elektrotechnische industrie aan de hand van schriftelijke en telefonische bestellingen.

De verkoopprijzen zijn afhankelijk van de afgenomen hoeveelheden en worden regelmatig aangepast aan wijzigende marktomstandigheden. Het metaalafval dat bij de productie ontstaat, wordt periodiek verkocht aan metaalhandelaren tegen dagprijzen.

De onderneming beschikt over een computer van voldoende capaciteit met terminals op diverse afdelingen. De computer is op ruime schaal ingeschakeld ten behoeve van de diverse bedrijfsactiviteiten.

\section{Gevraagd wordt:}

Een beschrijving van de administratieve organisatie.

Tevens dient een opsomming te worden gegeven van de relevante gegevenselementen, gegroepeerd naar computergegevensverzamelingen, ten behoeve van de planning van de inkoop en productie; een beschrijving van de inhoud van de overige bestanden is niet vereist. 


\section{Schema van uitwerking}

\section{Typering}

Het bedrijf kan worden getypeerd als een bedrijf met heterogene massaproductie.

\section{Aandachtspunten}

Aandacht dient te worden besteed aan onder meer de volgende punten:

- offerteprocedure;

- vreemde valutaproblematiek;

- planning inkopen en productie;

- economische voorraad problematiek;

- prijsrisico;

- productie;

- bewaking productiekosten;

- afval;

- bewaking volledigheid verkoopopbrengsten eindprodukten;

- idem: afval.

\section{Administratief-organisatorische randvoorwaarden}

\section{Functiescheidingen}

Functiescheiding tussen beschikken (inkoop, verkoop en directie), bewaren (magazijnen), registreren (administratie en automatiseringsafdeling), uitvoeren (productie) en controle (hoofd administratie). Binnen automatiseringsafdeling functiescheiding tussen systeemontwerp, bewaring bestanden en programma's en operating.

Maatregelen met betrekking tot automatisering

Genoemd dienen te worden (onder randvoorwaarden of in de uitwerking) de belangrijkste maatregelen op het gebied van:

- fysieke beveiliging;

- voorkoming ongeautoriseerde raadpleging/wijziging van bestanden en programma's (toegangsbeveiliging via wachtwoorden en competentietabel, bijhouden controletotalen door bijvoorbeeld hoofd administratie etc.);

- waarborging volledigheid/juistheid ingevoerde gegevens (gebruik voortellingen/natellingen, geprogrammeerde en ingebouwde invoercontroles, controle invoerverslag etc.);

- waarborging reconstructiemogelijkheden bestanden.

Richtlijnen directie

In de organisatie dienen door de directie geautoriseerde richtlijnen aanwezig te zijn met betrekking tot verkoopprijzen eindprodukten (afhankelijk van afgenomen hoeveelheden). De richtlijnen dienen aangepast te worden bij wijzigende marktomstandigheden.

Begroting/tariefcalculatie/standaard kostprijzen

Op basis van lange termijn omzetprognoses wordt verkoopbegroting voor komend jaar vastgesteld, waaruit inkoopbegroting en productiebegroting worden afgeleid.

Op grond hiervan worden kostenbegrotingen voor de diverse afdelingen vastgesteld waaruit manuuren machine-uurtarieven worden afgeleid. Met behulp van deze tarieven en technische productienormen (ook voor afval) worden voor de diverse produkten standaard-kostprijzen vastgesteld.

Begrotingen, tarieven en standaard-kostprijzen worden door de directie geautoriseerd.

Administratie rapporteert periodiek aan directie omtrent afwijkingen tussen werkelijkheid en begrotingen. 


\section{Beschrijving administratieve organisatie}

Inkopen

Inkoopafdeling vraagt aan de hand van inkoopdocumentatie periodiek en bij wijziging van marktomstandigheden, offertes aan bij leveranciers. Aangevraagde en ontvangen offertes worden geregistreerd evenals de beslissing omtrent de keuze van de leverancier en de overwegingen hierbij.

Inkoopafdeling voert de gegevens van de gekozen leverancier in de computer in (bijwerking leveranciersbestand).

Bestelling vindt plaats naar aanleiding van de planning van inkoop en productie (zie hierna) en de verwachte ontwikkeling van de inkoopprijzen.

Invoer goederenontvangsten door magazijn (bijwerking voorraadbestand) en ontvangen inkoopfacturen door administratie.

Controle inkoopfacturen door computer (vergelijking met bestelling, offerteprijs en goederenontvangst) en bijwerking leveranciersbestand.

De computer levert periodiek overzicht te betalen inkoopfacturen. Procuratiehouder tekent, na steekproefsgewijze controle, betalingsopdrachten en registreert die in delegatieregister.

Hoofd administratie controleert steekproefsgewijs aan de hand van de uitgebrachte offertes de genomen beslissingen inzake de keuze van de leveranciers.

Verder stemt hij periodiek de ingang van het voorraadbestand af met de ingang van het leveranciersbestand, alsmede de betalingen aan leveranciers met het delegatieregister en de uitgang van het leveranciersbestand.

N.B.: In plaats van 1 leveranciersbestand kan ook gebruik worden gemaakt van apart crediteurenbestand .

Planning inkoop en productie

Planning van inkoop en productie vindt plaats door bedrijfsbureau met behulp van computer naar aanleiding van de begrotingen, de werkelijke ontwikkeling van omzet en voorraden en norm- en capaciteitsgegevens. Door de computer worden concept-bestelopdrachten en concept-productie-opdrachten opgeleverd die worden beoordeeld door inkoopafdeling en bedrijfsbureau.

Voortgangscontrole vindt plaats met behulp van computer naar aanleiding van gegevens met betrekking tot goederenontvangst en productie.

Productie

Registratie materiaalverbruik, manuren, machine-uren, productie en afval in productierapporten per afdeling. Controle door administratie op geregistreerde kosten (afstemmen materiaalverbruik met uitgang voorraadbestand, afstemmen shoptime en jobtime en machine-uren met tellerstanden), productie (afstemmen met ingang voorraadbestand) en afval (vaststellen $\mathrm{kg}$-verband tussen materiaalverbruik, afval en eindprodukten).

Inbreng productierapporten in computer door administratie. Dagelijks ten behoeve van productiechefs en bedrijfsbureau door computer rapportering per afdeling van verschillen tussen verbruiken en normen (in hoeveelheden) alsmede afstemming afvalgegevens met normen. Ten behoeve van directie en hoofd productie periodieke rapportering per afdeling van werkelijke kosten en standaardkosten met analyse verschillen.

N.B.: Controle van de productiegegevens door middel van de computer is ook mogelijk.

Verkoop

Verkoopafdeling voert ontvangen orders in via terminal. Controle door computer op kredietwaardigheid 
klant (raadpleging afnemersbestand) en mogelijkheid tot tijdige levering (raadpleging voorraadbestand) en wegschrijving orders op orderbestand. Met behulp van orderbestand, afnemersbestand en voorraadbestand wordt dagelijks een factureer/afleverrun gedraaid waarbij bijwerking plaatsvindt van afnemersbestand (bijboeking debiteuren) en voorraadbestand (afboeking voorraden) en waarbij verkoopfacturen en afleveropdrachten worden uitgeprint.

Het hoofd van de administratie controleert of de verkoopprijzen overeenstemmen met de door de directie geautoriseerde verkoopprijzen, respectievelijk dagprijzen en stemt verkoopopbrengsten van eindprodukten en verkocht afval af met bijboeking debiteuren en afboeking voorraden. Tevens stemt hij ontvangen betalingen af met afboeking debiteuren.

Periodiek wordt naar aanleiding van het afnemersbestand een print gemaakt van achterstallige debiteuren die ter beoordeling wordt voorgelegd aan de verkoopafdeling.

Indien besloten wordt een afnemer van verdere levering uit te sluiten, wordt dit door middel van een code in het afnemersbestand ingebracht.

N.B.: In plaats van 1 afnemersbestand kan ook gebruik worden gemaakt van een apart debiteurenbestand.

Voorraden

Voorraden materialen en eindprodukten worden per artikelsoort geregistreerd tegen vaste verrekenprijzen of actuele prijzen (ook registratie gewicht).

Aparte registratie metaalafval (per soort). Per metaalsoort positie-administratie bijhouden (prijsrisico).

Hoofd administratie houdt kg-verbanden bij tussen afgegeven materialen, geproduceerde eindprodukten en metaalafval en inventariseert periodiek de voorraden.

Vreemde valuta

Per vreemde valutasoort dient een positie-administratie te worden bijgehouden (valutarisico).

Informatieverstrekking aan directie

De volgende informatie wordt per periode aan de directie verstrekt (met vermelding begrote cijfers en verklaring van afwijkingen):

- omzet en brutowinst (per artikelsoort);

- omzet afval;

- productieresultaten (per afdeling);

- bezettingsgegevens (per afdeling);

- ontwikkeling voorraden, debiteuren (ook achterstallig), crediteuren en liquide middelen:

- posities voorraden en vreemde valuta;

- ontwikkeling marktprijzen metalen;

- balans en resultatenrekening.

Opsomming van de relevante gegevenselementen, gegroepeerd naar computerbestanden, ten behoeve van planning, inkoop en productie

In deze bestanden dienen onder meer de volgende gegevens te worden opgenomen:

- begrotingsgegevens;

- omzetgegevens;

normen:

produktgegevens (stuklijsten etc.);

procesgegevens;

normen afval;

benodigde manuren en machine-uren;

- capaciteitsgegevens (per afdeling):

totale capaciteit (manuren/machine-uren);

- gereserveerde capaciteit;

- voorraadgegevens:

. $\quad$ aanwezige voorraden; 
gereserveerde voorraden;

levertijden;

lopende bestellingen;

- tarieven (manuur/machine-uur);

- voortgangsgegevens inkoop en productie. 


\section{Definitieve afgestemde checklist}

\begin{tabular}{||l|l||}
\hline Studentnummer: & $x$ \\
\hline Naam corrector: & \\
\hline Aantal jaren AO-correctie ervaring: & \\
\hline Aantal jaren ervaring in (interne of externe) accountantscontrole-praktijk & \\
\hline
\end{tabular}

\begin{tabular}{|c|c|c|}
\hline Code & Item & $\begin{array}{l}0=\text { afwezig of fout } \\
1=\text { aanwezig en juist }\end{array}$ \\
\hline 1 & Typologie en attentiepunten & \\
\hline 1.1 & Typologie=heterogene massaproductie & \\
\hline 1.2 & Attentiepunt=offerteprocedure & \\
\hline 1.3 & Attentiepunt=veemde valutaproblematiek & \\
\hline 1.4 & Attentiepunt=planning inkopen en productie & \\
\hline 1.5 & Attentiepunt=economische voorraadproblematiek & \\
\hline 1.6 & Attentiepunt=prijsrisico & \\
\hline 1.7 & Attentiepunt=bewaking productiekosten & \\
\hline 1.8 & Attentiepunt=volledigheid opbrengst verkopen & \\
\hline 1.9 & Attentiepunt=volledigheid opbrengst afval & \\
\hline 2 & Randvoorwaarden & \\
\hline 2.1 & Beschikken=inkoop, verkoop, directie & \\
\hline 2.2 & Bewaren=magazijnen & \\
\hline 2.3 & Registreren=administratie, automatisering & \\
\hline 2.4 & Uitvoeren=productie & \\
\hline 2.5 & Controle $=$ hoofd administratie & \\
\hline 2.6 & $\begin{array}{l}\text { Secundaire functiescheiding binnen automatisering=systeemontwerp, bewaring } \\
\text { bestanden/programma's, operating }\end{array}$ & \\
\hline 2.7 & Computerbeveiliging=fysieke beveiliging & \\
\hline 2.8 & Computerbeveiliging=wachtwoorden, login-procedures en competentietabel & \\
\hline 2.9 & Computerbeveiliging $=$ controletotalen door hoofd administratie & \\
\hline 2.10 & Computerbeveiliging=voortellingen en natellingen & \\
\hline 2.11 & Computerbeveiliging=geprogrammeerde en ingebouwde invoercontroles & \\
\hline 2.12 & Computerbeveiliging=controle invoerverslag & \\
\hline 2.13 & Computerbeveiliging=backup en recovery & \\
\hline 2.14 & Geautoriseerde directierichtlijnen inzake verkooprijzen & \\
\hline 2.15 & Directierichtlijnen aanpassen bij wijzigende marktomstandigheden & \\
\hline 2.16 & Verkoopbegroting op basis van lange termijn prognoses & \\
\hline 2.17 & Inkoopbegroting afgeleid uit verkoopbegroting & \\
\hline 2.18 & Productiebegroting afgeleid uit verkoopbegroting & \\
\hline 2.19 & Kostenbegroting afgeleid uit verkoopbegroting, inkoopbegroting en produc & \\
\hline
\end{tabular}




\begin{tabular}{|c|c|c|}
\hline 2.20 & Machine- en manuurtarieven afgeleid uit kostenbegroting & \\
\hline 2.21 & $\begin{array}{l}\text { Standaardkostprijzen voor produkten afgeleid uit tarieven en technische productienormen } \\
\text { (ook voor afval) }\end{array}$ & \\
\hline 2.22 & Autorisatie begrotingen, tarieven en standaardkostprijzen door directie & \\
\hline 2.23 & $\begin{array}{l}\text { Periodieke rapportage door administratie omtrent afwijkingen tussen realisatie en } \\
\text { begrotingen }\end{array}$ & \\
\hline 3 & Inkopen & \\
\hline 3.1 & $\begin{array}{l}\text { Inkoopafdeling vraagt offertes aan bij leveranciers op basis van inkoopdocumentatie: } \\
\text { - periodiek } \\
\text { - bij wijziging marktomstandigheden }\end{array}$ & \\
\hline 3.2 & Registratie aangevraagde offertes met vermelding van motief voor keuze leverancier & \\
\hline 3.3 & Bijwerken leveranciersbestand door inkoopafdeling v.w.b leveranciersgegevens & \\
\hline 3.4 & $\begin{array}{l}\text { Inkoopafdeling plaatst bestelling op basis van inkoop- en productieplanning en verwachte } \\
\text { ontwikkeling inkoopprijzen }\end{array}$ & \\
\hline 3.5 & Bijwerken voorraadbestand door magazijn & \\
\hline 3.6 & $\begin{array}{l}\text { Factuurcontrole door computer middels vergelijking met bestelling, offerteprijs en } \\
\text { goederenontvangst }\end{array}$ & \\
\hline 3.7 & $\begin{array}{l}\text { Bijwerken leveranciersbestand door administratie na factuurcontrole door computer } \\
\text { v.w.b. factuurgegevens }\end{array}$ & \\
\hline 3.8 & Geautomatiseerde aanmaak overzicht te betalen inkoopfacturen & \\
\hline 3.9 & Procuratiehouder tekent na steekproefsgewijze controle betalingsopdrachten & \\
\hline 3.10 & Procuratiehouder registreert getekende betalingsopdrachten in delegatieregister & \\
\hline 3.11 & $\begin{array}{l}\text { Aan de hand van de ontvangen offertes controleert hoofd administratie steekproefsgewijs } \\
\text { de beslissing inzake keuze van leverancier }\end{array}$ & \\
\hline 3.12 & $\begin{array}{l}\text { Hoofd administratie maakt periodiek de aansluiting tussen opboeking voorraadbestand } \\
\text { en opboeking leveranciersbestand }\end{array}$ & \\
\hline 3.13 & $\begin{array}{l}\text { Hoofd administratie maakt periodiek de aansluiting tussen betalingen aan leveranciers } \\
\text { conform delegatieregister en afboeking leveranciersbestand }\end{array}$ & \\
\hline 3.14 & Positie-administratie per vreemde valutasoort & \\
\hline 4 & Planning inkoop en productie & \\
\hline 4.1 & $\begin{array}{l}\text { Bedrijfsbureau maakt planning inkoop en productie op basis van begrotingen, werkelijke } \\
\text { omzet- en voorraadontwikkeling, norm- en capaciteitsgegevens }\end{array}$ & \\
\hline 4.2 & Geautomatiseerde aanmaak concept-inkoopbestellingen en productie-orders & \\
\hline 4.3 & $\begin{array}{l}\text { Beoordeling door computer aangemaakte concept-inkoopbestellingen en productie- } \\
\text { orders door respectievelijk inkoopafdeling en bedrijfsbureau }\end{array}$ & \\
\hline 4.4 & $\begin{array}{l}\text { Geautomatiseerde voortgangscontrole op basis van goederenontvangst- en } \\
\text { productiegegevens }\end{array}$ & \\
\hline 5 & Productie & \\
\hline 5.1 & $\begin{array}{l}\text { Afdelingen registreren materiaalverbruik, manuren, machine-uren, productie en afval in } \\
\text { productierapporten }\end{array}$ & \\
\hline 5.2 & $\begin{array}{l}\text { Administratie maakt aansluiting: materiaalverbruik volgens productierapporten met } \\
\text { afboeking voorraadbestand }\end{array}$ & \\
\hline 5.3 & Administratie maakt aansluiting: shoptime met jobtime volgens productierapporten & \\
\hline 5.4 & $\begin{array}{l}\text { Administratie maakt aansluiting: machine-uren volgens productierapporten met } \\
\text { tellerstanden }\end{array}$ & \\
\hline 5.5 & $\begin{array}{l}\text { Administratie maakt aansluiting: productie volgens productierapporten met opboeking } \\
\text { voorraadbestand }\end{array}$ & \\
\hline
\end{tabular}




\begin{tabular}{|c|c|c|}
\hline 5.6 & $\begin{array}{l}\text { Administratie maakt aansluiting: afvalnorm * productie met afval volgens } \\
\text { productierapporten }\end{array}$ & \\
\hline 5.7 & Administratie voert productierapporten in & \\
\hline 5.8 & $\begin{array}{l}\text { Geautomatiseerde dagelijkse rapportage aan productiechefs en bedrijfsbureau inzake } \\
\text { verschillen tussen verbruiken en normen in hoeveelheden (materiaalverbruik, manuren, } \\
\text { machine-uren, productie en afval) }\end{array}$ & \\
\hline 5.9 & $\begin{array}{l}\text { Periodieke rapportage door administratie aan directie en hoofd productie inzake } \\
\text { verschillen tussen werkelijke kosten en standaardkosten met verschillenanalyse }\end{array}$ & \\
\hline 6 & Verkoop & \\
\hline 6.1 & Verkoopafdeling voert ontvangen orders is via terminal & \\
\hline 6.2 & $\begin{array}{l}\text { Geprogrammeerde controle op kredietwaardigheid klant middels raadpleging } \\
\text { afnemersbestand }\end{array}$ & \\
\hline 6.3 & $\begin{array}{l}\text { Geprogrammeerde controle op mogelijkheid tot tijdige levering middels raadpleging van } \\
\text { het voorraadbestand }\end{array}$ & \\
\hline 6.4 & $\begin{array}{l}\text { Na geprogrammeerde controles op kredietwaardigheid en mogelijkheid tot tijdige levering } \\
\text { wegschrijven orders naar orderbestand }\end{array}$ & \\
\hline 6.5 & $\begin{array}{l}\text { Dagelijke facturering middels het uitdraaien van facturen op basis van orderbestand, } \\
\text { afnemersbestand en voorraadbestand }\end{array}$ & \\
\hline 6.6 & Opboeking afnemersbestand op basis van aangemaakte facturen & \\
\hline 6.7 & $\begin{array}{l}\text { Dagelijkse uitdraai afleveropdrachten ten behoeve van magazijn op basis van } \\
\text { orderbestand, afnemersbestand en voorraadbestand }\end{array}$ & \\
\hline 6.8 & Afboeking voorraadbestand op basis van magazijnafgiften & \\
\hline 6.9 & $\begin{array}{l}\text { Hoofd administratie controleert of de verkoopprijzen volgens facturen overeenstemmen } \\
\text { met de door de directie geautoriseerde verkoopprijzen c.q. dagprijzen }\end{array}$ & \\
\hline 6.10 & $\begin{array}{l}\text { Hoofd administratie maakt aansluiting: verkoopopbrengsten (zowel eindprodukten als } \\
\text { afval) met opboeking debiteuren en afboeking voorraden }\end{array}$ & \\
\hline 6.11 & $\begin{array}{l}\text { Hoofd administratie maakt aansluiting: ontvangen betalingen volgens dagafschriften met } \\
\text { afboeking debiteuren }\end{array}$ & \\
\hline 6.12 & $\begin{array}{l}\text { Periodieke aanmaak lijst van achterstallige debiteuren op basis van afnemersbestand en } \\
\text { beoordeling door verkoopafdeling }\end{array}$ & \\
\hline 6.13 & $\begin{array}{l}\text { Indien verkoopafdeling besluit tot uitsluiting afnemer van verdere levering wordt } \\
\text { statuscode in afnemersbestand aangepast }\end{array}$ & \\
\hline 7 & Voorraden & \\
\hline 7.1 & $\begin{array}{l}\text { Voorraden materialen en eindprodukten worden per artikelsoort geregistreerd in } \\
\text { hoeveelheden en tegen vaste verrekenprijzen of actuele prijzen }\end{array}$ & \\
\hline 7.2 & Metaalafval wordt per soort geregistreerd & \\
\hline 7.3 & Positie-administratie van metaalafval & \\
\hline 7.4 & $\begin{array}{l}\text { Hoofd administratie maakt aansluiting: gewicht afgegegeven materialen met gewicht } \\
\text { geproduceerde eindprodukten en metaalafval }\end{array}$ & \\
\hline 7.5 & Periodieke inventarisatie voorraden onder verantwoordelijkheid hoofd administratie & \\
\hline 8 & Gegevensverzamelingen & \\
\hline 8.1 & Begrotingsgegevens & \\
\hline 8.2 & Omzetgegevens & \\
\hline 8.3 & Productienormen & \\
\hline 8.4 & Afvalnormen & \\
\hline 8.5 & are capaciteit per afdeling & \\
\hline
\end{tabular}




\begin{tabular}{|c|c|c|}
\hline 8.6 & Gereserveerde capaciteit per afdeling & \\
\hline 8.7 & Aanwezige voorraden & \\
\hline 8.8 & Gereserveerde voorraden & \\
\hline 8.9 & Levertijden & \\
\hline 8.10 & Tarieven voor man- en machine-uren & \\
\hline 8.11 & Voortgangsgegevens inkoop en productie & \\
\hline 9 & Informatieverstrekking aan directie & \\
\hline 9.1 & Realisatie versus begroting met verklaring van afwijkingen & \\
\hline 9.2 & Omzet en brutowinst per artikelsoort & \\
\hline 9.3 & Omzet afval & \\
\hline 9.4 & Productieresultaten per afdeling & \\
\hline 9.5 & Bezettingsgegevens per afdeling & \\
\hline 9.6 & Ontwikkeling voorraden, debiteuren, crediteuren en liquide middelen & \\
\hline 9.7 & Posities voorraden & \\
\hline 9.8 & Posities vreemde valuta & \\
\hline 9.9 & Ontwikkeling marktprijzen metalen & \\
\hline 9.10 & Balans en resultatenrekening & \\
\hline 10 & Algemeen & \\
\hline 10.1 & Geen 'blunders' aanwezig (n.b.: $0=$ oneens, $1=$ eens) & \\
\hline 10.2 & Goed lopend verhaal ( $\mathrm{n}$.b.: $0=$ oneens, $1=$ eens) & \\
\hline
\end{tabular}

Eindcijfer student x (één decimaal) 


\section{Bijlage 2}

Instructies ten behoeve van de onafhankelijke derde inzake de matching van de checklists van de samenstellers

1. Neem één van beide lijsten als uitgangspunt (noem dit lijst $A$ ) en blijf deze als uitgangspunt hanteren. De andere lijst wordt lijst $B$ genoemd.

2. Zoek per item uit lijst $A$ het equivalent in lijst $B$. Vink in beide lijsten af.

3. Indien het item uit lijst $A$ eveneens (eventueel in andere bewoordingen) aanwezig is in lijst $B$, neem dit item dan op in de afgestemde lijst (eventueel na aanpassing van de bewoordingen). Geef aan dit item in de afgestemde lijst de code ' $J J$ '.

4. Indien het item uit lijst A niet aanwezig is in lijst B, wordt het item desalniettemin in de afgestemde lijst opgenomen. Geef aan dit item de code 'JN'.

5. Indien alle items uit lijst A zijn behandeld, zoek dan in lijst B naar nog niet afgevinkte items. Neem deze niet afgevinkte items op in de afgestemde lijst. Geef aan deze items de code ' $\mathrm{NJ}$ '.

6. Maak een classificatie van alle in de afgestemde lijst opgenomen items op basis van de classificatie in lijst A. De niet in desbetreffende classificatie passende items worden geclassificeerd volgens de classificatie in lijst B.

7. Nummer de items conform vorengenoemde classificatie.

8. Bespreek de items die voorzien zijn van de code 'JN' danwel ' $\mathrm{NJ}$ ' met de samenstellers van de lijsten A en B. Deze bespreking leidt tot de definitieve afgestemde lijst. 
Literatuur

Ashton, R.H., An Experimental Study of Internal Control Judgments, Journal of Accounting Research, Spring, 1974

Ashton, A.H., Does Consensus Imply Accuracy in Accounting Studies of Decision Making?, The Accounting Review, Vol. 60, 1985

Ashton, R.H., Brown, P.R., Descriptive Modeling of Auditors' Internal Control Judgments: Replication and Extension, Journal of Accounting Research, Spring, 1980

Ashon, R.H., Kramer, S.S., Students as Surrogates in Behavioral Research: Some Evidence, Journal of Accounting Research, Spring, 1980

Bedard, J., Expertise and its Relation to Audit Decision Quality, Contemporary Accounting Research, Vol. 8, No. 1, Fall, 1991

Bonner, S.E., Lewis, B.L., Determinants of Auditor Expertise, Journal of Accounting Research, Vol. 28, Supplement, 1990

Brown, R.G., Objective Internal Control Evaluation, Journal of Accountancy, November 1962

Gaumnitz, B.R., Nunamaker, T.R., Surdick, J.J., Thomas, M.F., Auditor Consensus in Internal Control Evaluation and Audit Program Planning, Journal of Accounting Research, Vol. 20, No. 2, Autumn, 1982

Huber, V.L., Comparison of the Effects of Specific and General Performance Standards on Performance Appraisal Decisions, Decision Sciences, 1989

Ilgen, D.R., Barnes-Farrell, J.L., McKellin, D.B., Performance Appraisal Process Research in the 1980's: What has it Contributed to Appraisals in Use?, Organizational Behavior and Human Decision Processes, 1993

Joyce, E.J., Expert Judgment in Audit Program Planning: an Empirical Study, Studies on Human Information Processing in Accounting, Supplement to the Journal of Accounting Research, 14, pp. 29-60, 1976

Kachelmeier, S.J., Messier, W.F., An Investigation of the Influence of a Nonstatistical Decision Aid on Auditor Sample Size Decisions, The Accounting Review, Vol. 65, No. 1, January, 1990

Libby, R., Luft, J., Determinants of judgment performance in accounting settings: ability, knowledge, motivation, and environment, Accounting, organizations and society, 18, 1993

Luckett, P.F., Eggleton, I.R., Feedback and Management Accounting, Accounting Organizations and Society, 1991

Milkovich, G.T., Newman, J.M., Compensation, Homewood, 1993

Mock, T.J., Turner, J.L., Internal Accounting Control Evaluation and Auditor Judgment, Auditing Monograph no. 3, AICPA, New York, 1981

Moriarity, S., Barron, F.H., Modeling the Materiality Judgments of Audit Partners, Journal of Accounting Research, Autumn, 1976

Moriarity, S., Barron, F.H., A Judgment-Based Definition of Materiality, Studies on Auditing, Selections from the 'Research Opportunities in Auditing'-Program, Supplement to Journal of Accounting Research, 1979

Murphy, D.S., Expert System Use and the Development of Expertise in Auditing: a Preliminary Investigation, Journal of Information Systems, Fall, 1990

Tabor, R.H., Internal Control Evaluations and Audit Program Revisions: Some Additional Evidence, Journal of Accounting Research, Vol. 21, No. 1, 1983

Tversky, A., Features of Similarity, Psychological Review, 1977

Waller, W.S., Felix, W.L., The Auditor and Learning from Experience: Some Conjectures, Accounting Organizations and Society, Vol. 9, No. 3/4, 1984

Weber, R., Auditor Decision Making on Overall System Reliability: Accuracy, Consensus and the Usefulness of a Simulation Decision Aid, Journal of Accounting Research, Autumn, 1978 